Western North American Naturalist 67(3), ㄷ 2007, pp. 389-401

\title{
CHANGES IN KIT FOX-COYOTE-PREY RELATIONSHIPS IN THE GREAT BASIN DESERT, UTAH
}

\author{
Wendy M. Arjo ${ }^{1}$, Eric M. Gese ${ }^{2}$, Tim J. Bennett ${ }^{3}$, and Adam J. Kozlowski ${ }^{4}$
}

\begin{abstract}
Variation in kit fox (Vulpes macrotis) population parameters can be influenced by vegetative cover and the distribution and abundance of other predator and prey species. Dramatic changes to Great Basin Desert habitats, which can potentially impact mammalian species, have occurred in some areas in Utah. We examined kit fox demographics and prey populations from 1999 to 2001 on Dugway Proving Ground (DPG), a U.S. Army facility in Utah, and compared some parameters to historical levels (1956-1958, 1966-1969). Adult survival rates were fairly consistent between 1999 and 2000 and between 1999 and 2001; however, survival was greater in 2001 than in 2000. Reproductive rates ranged from 1.0 to 3.8 pups per female in 1999-2000 and were similar to historical numbers (1.0-4.2 pups per female). We found a decrease in pre-whelping kit fox density from the $1960 \mathrm{~s}\left(0.12\right.$ foxes $\left.\cdot \mathrm{km}^{-2}\right)$ to $1999-2001(0.04$ foxes $\left.\cdot \mathrm{km}^{-2}\right)$; however, densities were similar between the current study and the $1950 \mathrm{~s}\left(0.08\right.$ foxes $\left.\cdot \mathrm{km}^{-2}\right)$. Using 9 years of data, we found density dependence between reproductive rates of the current year and annual fox density from the previous year. Using 7 years of data, we found a slight correlation between kit fox annual density and a 1-year lag in leporid abundance, even though leporid abundance was lower during the present study than it was historically. Compared to historical levels, current small mammal abundance and species composition has changed in several habitats. Kit fox breeding density and annual density were inversely correlated with coyote (Canis latrans) density. Changes to the landscape at DPG, especially due to invasion of cheatgrass (Bromus tectorum) and addition of artificial water sources, have caused a change in available kit fox habitat and prey species, and have increased the abundance of coyotes, the kit fox's major competitor.
\end{abstract}

Key words: coyote, demographics, exotic annuals, jackrabbit, kit fox, leporids, small mammals.

Kit fox (Vulpes macrotis) populations are often characterized as fluctuating dramatically from year to year (Cipher and Scrivener 1992, White and Walls 1993, Cipher and Spencer 1998, White and Garroted 1999). Natural forces affecting carnivore population demographics and viability include short- and long-term changes in prey abundance and availability (Fuller and Savored 2001) and competition with other predator species. For example, on the Carrizo Plain Natural Area in California, a decrease in breeding kit foxes was observed following a decrease in prey availability (White and Walls 1993). Spiegel and Disney (1996) also documented a decrease in the proportion of females successfully rearing pups during a period of low prey availability in Kern County, California.

Leporids are considered the main prey of kit foxes (White and Garroted 1997), and several studies document the relationship between leporid density and kit fox density
(White and Garroted 1997, White and Garroted 1999, Dennis and Often 2000). However, kit foxes are also dependent on other prey species (Zoellick and Smith 1992, White et al. 1995, Cipher et al. 2000), such as kangaroo rats (Dipodomys spp.), yet the relationship between fox density and small mammal abundance has rarely been examined. Kit fox home ranges tend to be small and they overlap in areas with large abundant prey such as leporids (O'Neal et al. 1987, Zoellick et al. 1989, White and Walls 1993), but home ranges are large and exclusive when small nocturnal rodents are the primary prey source (Zoellick and Smith 1992).

Behavioral spacing mechanisms (White and Garroted 1997) and populations of competing predators (Cipher and Scrivener 1992, White et al. 1995, Cipher and Spencer 1998) may act in concert to regulate kit fox densities. However, resources must first be limited for social behavior to regulate populations (Pierce et al.

\footnotetext{
${ }^{1}$ USDA APHIS WS National Wildlife Research Center, 9730-B Lathrop Industrial Drive, Olympia, WA 98512. Email: wendy.m.arjo@aphis.usda.gov

${ }^{2}$ USDA APHIS WS National Wildlife Research Center, Utah State University, Logan, UT 84322-5295.

${ }^{3}$ AGEISS Environmental, Inc., Box 463, Dugway, UT 84022.

${ }^{4}$ Utah Division of Wildlife Resources, Northern Region, 515 East 5300 South, Ogden, UT 84055.
} 
2000). Intraspecific behavioral spacing mechanisms, which limit recruitment of juveniles and immigrants into the population (White and Garroted 1999), in addition to interspecific competition for habitat with coyotes (Canis latrans), can affect kit fox population size. Direct competition with coyotes for food resources has been documented in several studies (Cipher et al. 1994, White et al. 1995, Cipher and Spencer 1998). In addition, coyotes are the main source of mortality in several kit fox populations (Cipher and Scrivener 1992, Walls and White 1995, Cipher and Spencer 1998).

Egoscue (1956, 1962, 1975) documented kit fox densities and reproduction on Dugway Proving Ground (DPG), a U.S. Army facility in Utah, during and following its inception as a military testing site. Several other studies at the time also documented leporid abundance and vegetation communities and their associated small mammal assemblages (Vest 1962, Eberhardt and Van Voris 1986). Since these early studies, dramatic changes to DPG's habitat composition have occurred. Although not historically present as a community type, annual grasslands of mostly exotic annuals have invaded and dominated large areas of DPG. Over $60 \%$ of the original mixed-brush community described by Vest (1962) and 40\% of the juniper-brush community have been replaced by exotics (DPG unpublished data). Disturbance from natural and human-caused fires and from military maneuvers have allowed displacement of natural vegetation by exotic annuals such as cheatgrass (Bromus tectorum), tumbling mustard (Sisymbrium altissimum), Russian thistle (Salsola iberica), and peppercress (Lepidium perfoilatum). These changes to the habitat have affected the distribution, abundance, and diversity of small mammals (Carpenter and Arjo 1999), which in turn may affect kit fox reproductive success and population size (White and Walls 1993, Cipher et al. 2000) and may increase competition with other predators.

Although the kit fox population on DPG is not endangered like the San Joaquin kit fox ( $V$. macrotis mutica) population, kit fox is a "species of concern" to wildlife managers on DPG. Kit fox was the most common carnivore on DPG through the 1960s (Egoscue 1975); however, recent observations suggest that populations of leporids and kit fox are declining, while coyotes are increasing. We exam- ined kit fox demographics and the relationships of kit fox with both small mammal and leporid prey species. In addition, we compared historical kit fox abundance, coyote abundance, and prey data to the current study to determine if changes in predator-predator and predatorprey relationships have occurred in the last 30 years.

\section{STUdy AREA}

Dugway Proving Ground is located $128 \mathrm{~km}$ southwest of Salt Lake City in Tooele County, Utah, and covers $3330 \mathrm{~km}^{2}$ of Great Basin Desert habitat. Elevation ranges from $1288 \mathrm{~m}$ on the salt playa flats to $2154 \mathrm{~m}$ in mountainous areas. Due to its midlatitude location, this arid region is often characterized as cold desert. Winters are usually cold, and summers are hot and dry, with the majority of the precipitation falling in spring. Average maximum temperatures on DPG range from $3.3^{\circ} \mathrm{C}$ in January to $34.7^{\circ} \mathrm{C}$ in July. Average minimum temperatures range from $-8.8^{\circ} \mathrm{C}$ in January to $16.3^{\circ} \mathrm{C}$ in July. Mean annual precipitation is $20.07 \mathrm{~cm}$.

Most of DPG consists of salt playa flats, remnants from Lake Bonneville, sparsely vegetated with pickleweed (Allenrolfea occidentalis). Playa areas, with more developed soils, less salt, and more moisture, support advanced seral stages of halophytic cold-desert shrub communities. Low shrubby shadscale (Atriplex confertifolia) and gray molly (Kochia americana) are characteristic of the cold-desert chenopod community. Greasewood (Sarcobatus vermiculatus) is often associated with these shrubs, as well as mound saltbush (Atriplex gardneri) and Torrey seepweed (Suaeda torreyana). A slight increase in elevation and a greater retention of water led to more diverse habitats on DPG, namely the vegetated sand dunes. Several varieties of shrubs, including fourwing saltbush (Atriplex canescens), greasewood, viscid rabbitbrush (Chrysothamnus viscidiflorus), hopsage (Grayia spinosa), dune rabbitbrush (C. nauseosus var. turbinatus), shadscale, and horsebrush (Tetradymia glabrata), are found in the dunes. Forbs, native perennials, and grasses are also common in the vegetated dunes. Interspersed in the flat terrain are steep mountain ranges that are cooler and more mesic. Shrubsteppe communities occur at the bases of the higher mountains, and along the slopes of the smaller mountains, and these 
communities are dominated by sagebrush (Artemisia spp.), viscid rabbitbrush, Nevada ephedra (Ephedra nevadensis), greasewood, and shadscale. At higher elevations and through portions of the vegetated dunes is the Utah juniper (Juniper osteosperma) community. Often associated with this community is black sagebrush (Artemisia nova) and bluebunch wheatgrass (Elymus spicatus).

In addition to kit fox and coyote, other carnivores include cougar (Puma concolor), bobcat (Lynx rufus), and more recently, red fox (V. vulpes). Although pronghorn (Antilocapra americana) and mule deer (Odocoileus hemionus) are present on DPG, these are not considered prey for kit fox, but they may be ingested as carrion. Prey species include black-tailed jackrabbit (Lepus californicus), mountain cottontail (Sylvilagus nuttalli), woodrats (Neotoma spp.), and several species from the families Heteromyidae and Muridae.

\section{Methods}

\section{Kit Fox Demographics}

We trapped around known kit fox dens and in areas of suspected occupancy and combined those trapping data with data from transect trapping surveys (Schauster et al. 2002) conducted from December 1998 through February 2001 within a $264-\mathrm{km}^{2}$ area of DPG. This area encompassed Egoscue's original 65$\mathrm{km}^{2}$ study site (Egoscue 1956) and $104 \mathrm{~km}^{2}$ from his 1962 study site (Egoscue 1962, 1975). Kit foxes were captured with double-door box traps $(80 \times 25 \times 25 \mathrm{~cm}$; Tomahawk Live Trap Company, Tomahawk, WI) that were baited with raw chicken or bacon. Traps were deployed in the evening and checked early each morning. Kit foxes were removed from the trap by placing a cotton bag over 1 end of the trap and coaxing the fox into the bag. Once the animal was secured in the bag, it could be removed and handled without the use of drugs. Foxes were sexed, weighed, measured, and then aged based on tooth wear and body size. Kit foxes were considered juveniles until the breeding season $(15 \mathrm{Dec})$ following their birth, at which time they were considered adults. Each kit fox that weighed $>1 \mathrm{~kg}$ was fitted with a mortality-sensor transmitter weighing 30-50 g (Holihil, Toronto, Canada, or Advanced Telemetry Systems, Isanti, MN). Animals were examined for external wounds and parasites, and any lac- erations were treated with antiseptic. All kit foxes were released at the capture site.

We used a portable receiver (Telonics, Inc., Mesa, AZ) and a handheld 3-element Yagi antenna to locate animals $\geq 3$ times a week. In addition, aerial locations were obtained approximately every 3 weeks. Telemetry procedures followed recommendations by White and Garroted (1990). Fox locations were triangulated using the LOCATE (Pacer, Truro, Nova Scotia) software package with $\geq 2$ bearings taken $<10$ minutes apart. To minimize triangulation error, bearings that intersected at $\leq 20^{\circ}$ or $\geq 160^{\circ}$ were censored from the analyses (Gese et al. 1988). We monitored radio-marked foxes to determine causes of mortality. The possible cause of mortality was determined by examining the carcass for external and internal injuries, puncture wounds, and hemorrhaging. Physical evidence at the site of mortality, such as tracks, scat, or hair, also assisted us in determining the possible cause of death. Annual survival rates for 1999, 2000, and 2001, and for males and females over the entire study period, were extrapolated from daily survival rates using MICROMORT (Heisey and Fuller 1985).

Kit fox densities were determined for the overall study site by using a delineated study area from a $100 \%$ minimum convex polygon around locations (Pooele et al. 1996) divided by the number of known kit foxes in that area. Densities were determined as annual densities (1999 and 2000) and pre-whelping densities (animals present in the study area between 15 December and 14 April). We did not determine an annual density of kit foxes in 2001 because data could only be collected for 4 months. This method biases densities downward due to uncaptured animals, but it is similar to methods used by Egoscue to estimate densities. Reproductive rates were determined each spring through litter counts conducted at dens. These reproductive rates are conservative estimates because only pups that emerged from the den were recorded.

\section{Coyote Abundance}

We determined coyote abundance from historical and current records of aerial hunting by USDA APHIS Wildlife Services in the state of Utah. Coyote abundance was standardized by the number of coyotes taken per hour of aerial hunting. Years for which hours of hunting were not recorded were excluded 
from the analyses. We compared kit fox annual and pre-whelping densities to coyote densities using regression analysis $\left(\mathrm{SAS}^{\circledR}\right.$, version 8.0, SAS Institute, Inc., Cary, NC).

\section{Small Mammal Abundance}

We determined small mammal densities for 2 time periods over 2 years: June and September. The 6 dominant habitats, which were identified first by Vest (1962) and later redefined by Emrick and Hill (1998), were trapped with 3 replicates of each habitat: grassland (exotic annuals), chenopod, pickleweed, vegetated dune, greasewood, and shrubsteppe. Kit fox home ranges were known to incorporate portions of each of these habitats (Arjo et al. 2003). When possible, we used the original habitat study plots, which were identified by Vest (1962) and were later used by AGEISS (1997, 1998). We chose replicates, based on vegetation maps produced by DPG, of the habitats to increase our ability to accurately reflect the abundance and diversity of small mammal species in each habitat type.

A trapping grid for each replicate consisted of 64 traps (H.B. Sherman Traps, Tallahassee, FL) placed $10 \mathrm{~m}$ apart in an $8 \times 8$ grid. Each trap was baited with a mixture of peanut butter and oats, and each grid was active for a 4night period. Captured animals were identified, weighed, and sexed. Black hair dye or a permanent marker was used to mark animals before release. Historical trapping (Vest 1962, AGEISS 1997, 1998) was conducted on a $14 \times$ 14 grid for 8 consecutive nights. To compare current and historical small mammal data, only the first 4 nights of historical trapping data were used. In addition, we weighted the number of small mammal captures for each time period based on size of the trapping grid.

A Kruskal-Wallis test $(H)$ for nonparametric data was used to determine if the abundances of small mammals were similar in each habitat replicate for the current trapping effort. If replicates were similar, we pooled habitat replicates to describe specific habitats across DPG. We used ANOVA to test for differences in abundance between the habitats for each season and year (1999 and 2000; Zar 1996). Tukey's multiple comparison tests were used to identify differences within the levels of significant variables. Shannon diversity indices $\left(H^{\prime}\right)$ were calculated for each habitat type and compared between current habitat types and between Vest's 1956/1957 data using a $t$ test (Zar 1996).

Historical small mammal abundance data (Vest 1962) in each habitat were not replicated and trap-night effort varied; therefore, statistical comparisons between historic and current data were not possible. We used an index standardized by individuals per trap-night to graphically represent changes in small mammal abundance in the 4 habitats. We used linear regression to determine if kit fox densities were correlated with small mammal indices, and if reproductive rates were correlated with small mammal indices using both our data and historical fox data (Egoscue 1962, 1975; H. Egoscue unpublished data). We compared small mammal indices from the spring and summer to determine if the previous year's precipitation influenced densities. Precipitation information was collected from a weather station established at the Ditto Area on DPG. In addition, kit fox reproductive rates, pre-whelping densities, and annual densities were compared to small mammal indices.

\section{Leporid Abundance}

Leporid populations, which consisted of only jackrabbits, were estimated using quarterly spotlight surveys along 6 transects from May 1999 through May 2001. Surveys were conducted for 3 nights with a minimum of 1 night between surveys to minimize any influence of weather. Only 2 surveys were conducted in 2001 (February and May) due to the completion of the study. Surveys began no earlier than 1 hour after sunset. The number of leporids per kilometer was determined as an average for the 3 nights. Daytime surveys for leporids were conducted from 1965 through 1985 in March and August. We did not continue to conduct daylight surveys during the current study because of the low numbers of rabbits observed during this time (Arjo personal observation). Differences in leporid abundances between pre- and postreproductive seasons (May and August) along the 6 transects were determined using ANOVA (SAS ${ }^{\circledR}$, version 8.0, SAS Institute, Inc., Cary, NC). We performed linear regression using both our data and historical fox data (Egoscue 1962, 1975; Egoscue unpublished data) to determine if kit fox densities or reproductive rates were correlated with 
TABLE 1. Survival rates for adult kit foxes of known and unknown fates on Dugway Proving Ground, Utah, 1999-2001.

\begin{tabular}{|c|c|c|c|c|c|c|c|c|c|c|}
\hline \multirow[b]{2}{*}{ Interval } & \multicolumn{5}{|c|}{ Kit foxes of known fate } & \multicolumn{5}{|c|}{ Kit foxes of unknown fate } \\
\hline & $n$ & Rate & Variance & $\begin{array}{c}\mathrm{L}_{1} \\
\text { (lower) }^{\mathrm{a}}\end{array}$ & $\begin{array}{c}\mathrm{L}_{2} \\
\text { (upper) }\end{array}$ & $n$ & Rate & Variance & $\begin{array}{c}\mathrm{L}_{1} \\
\text { (lower) }^{\mathrm{a}}\end{array}$ & $\begin{array}{c}\mathrm{L}_{2} \\
\text { (upper) }\end{array}$ \\
\hline \multicolumn{11}{|c|}{ Study period } \\
\hline Males & 10 & 0.322 & 0.0403 & 0.09 & 1.0 & 13 & 0.108 & 0.00897 & 0.019 & 0.603 \\
\hline Females & 9 & 1.0 & - & - & - & 9 & 0.502 & 0.0299 & 0.256 & 0.986 \\
\hline \multicolumn{11}{|l|}{ Annual } \\
\hline 1999 & 13 & 0.853 & 0.0184 & 0.624 & 1.0 & 15 & 0.556 & 0.02665 & 0.312 & 0.988 \\
\hline 2000 & 11 & 0.711 & 0.0196 & 0.483 & 1.0 & 15 & 0.517 & 0.01663 & 0.317 & 0.842 \\
\hline 2001 & 11 & 1.0 & - & - & - & 11 & 1.0 & - & - & - \\
\hline
\end{tabular}

August leporid abundance. We used precipitation data gathered at DPG to examine the influence of precipitation on leporid abundance. Kit fox reproductive rates, pre-whelping densities, and annual densities were compared to August leporid densities. Small mammals and leporids depend on vegetation and seed production, and in drought years, vegetative growth may be diminished, which in turn affects rodent densities through decreased reproduction. We used a 1-year lag to account for the numerical response of leporids to vegetative growth.

\section{RESUlTS}

\section{Kit Fox Demographics}

We captured 27 kit foxes, 10 females and 17 males, from December 1998 through February 2001. Twenty adults and 7 juveniles were radio-collared and monitored. Two of the juveniles were also monitored as adults. Predation accounted for 5 kit fox deaths. We also recovered the collars from 2 additional adult kit foxes. Puncture marks and blood were found on 1 of these collars from a female, and we assumed that she was killed by a predator. We were unable to determine the fate of the other animal. Signals of 4 adults were lost, and these animals were never recovered, trapped, or seen again.

Male survival rates were significantly less than female survival rates over the entire study period $(z=3.38, P=0.0004$; Table 1$)$. Adult annual survival rate was consistent between 1999 and 2000, and between 1999 and 2001; however, kit fox survival was greater in 2001 than in $2000(z=2.06, P=0.02)$. Female survival for the entire study was reduced from
1.0 to 0.502 when we considered unknown fates (e.g., loss of radio signals or collars recovered without the associated individual) of animals as mortalities $(z=2.8, P=0.002)$. Male overall survival changed very little when unknown fates were considered (known fate: 0.322; unknown fate: 0.108 ).

We only tracked the fates of a few juveniles ( $n=5$ males and 2 females) because of the poor weather during the early trapping season (July or August). We monitored 1 juvenile male for 2 years until we lost the signal. Because we were unable to locate his signal during telemetry flights over a $20-\mathrm{km}$ radius from his last known location, it is likely his transmitter failed. Another juvenile male was killed by a coyote a few days after capture. One juvenile female survived the duration of the study, and the other was killed by a coyote before she reached 1 year of age. Three juvenile males dispersed south and east from DPG. We recovered the collar from 1 of these juveniles, but we were unable to determine the cause of death for another. During a telemetry flight, we located the 3 rd juvenile $>25 \mathrm{~km}$ south of DPG shortly before his signal was lost.

We documented a decrease in pre-whelping kit fox density from the 1960s $(0.12$ foxes $\mathrm{km}^{-2}$ ) to 1999-2001 (0.04 foxes $\cdot \mathrm{km}^{-2}$ ). Reproductive rates were lower in 1999 than they were in the following 2 years $\left(\chi^{2}=7.26, \mathrm{df}=\right.$ $2, P=0.03)$, when they were relatively constant $\left(\chi^{2}=1.16\right.$, df $=1, P=0.3$; Table 2). Though we tried to observe dens of every collared female in 1999, only 1 female was seen with pups. We believed that a playa flats pair had pups in 2000 because of the excavation activity at the den, but the pair abandoned the site in early May after a bomb exploded during army activities close to their den. Although 
TABLE 2. Historical and recent kit fox demographics and prey abundance indices on U.S. Army Dugway Proving Ground, Utah.

\begin{tabular}{lccccc}
\hline Year & $\begin{array}{c}\text { Number of } \\
\text { females }\end{array}$ & $\begin{array}{c}\text { Number of } \\
\text { pups }\end{array}$ & $\begin{array}{c}\text { Reproductive rate } \\
\text { (pups per female) }\end{array}$ & $\begin{array}{c}\text { Spring small } \\
\text { mammal index }\end{array}$ & $\begin{array}{c}\text { Fox density- } \\
\text { breeding }\end{array}$ \\
\hline 1955 & 5 & 21 & 4.2 & - & 0.06 \\
1956 & 4 & 4 & 1.0 & 0.1 & 0.15 \\
1957 & 4 & 3 & 0.75 & 0.07 & 0.03 \\
1958 & 5 & 9 & 1.8 & $0.27^{\mathrm{a}}$ & 0.09 \\
1966 & 11 & 30 & 2.72 & $0.05^{\mathrm{b}}$ & 0.12 \\
1967 & 10 & 15 & 1.5 & $0.27 \mathrm{c}$ & 0.11 \\
1968 & 8 & 11 & 2.5 & $0.34^{\mathrm{d}}$ & 0.11 \\
1969 & 4 & 10 & 2.0 & 0.02 & 0.02 \\
1996 & 6 & 12 & 1.0 & 0.01 & 0.03 \\
1997 & 4 & 8 & 2.14 & 0.07 & 0.06 \\
1999 & 5 & 5 & 3.8 & 0.07 & 0.05 \\
2000 & 7 & 15 & & - & \\
2001 & 5 & 19 & &
\end{tabular}

${ }^{\mathrm{a}} \mathrm{E} \& \mathrm{E}$ Research Group 1967

$\mathrm{b}_{\mathrm{E}} \& \mathrm{E}$ Research Group 1968

${ }^{\mathrm{c}} \mathrm{E} \& \mathrm{E}$ Research Group 1969

$\mathrm{d}_{\mathrm{E}} \&$ E Research Group 1970

no pups were seen with this pair in 2000 , they produced 3 pups in 2001.

Reproductive rates in our study were comparable to historical reproductive rates $\left(F_{6,23}\right.$ $=0.92, P=0.5)$. Though current pre-whelping fox densities were lower than 1960 densities $(t=8.88, P=0.001)$, current fox prewhelping densities were similar to densities observed in the 1950s $(t=1.80, P=0.17)$. Reproductive rates were inversely related to annual fox density from the previous year (Fig. $\left.1 ; R^{2}=0.479, F_{1,7}=6.45, P=0.04\right)$. However, when the data point for 2001 was removed, this relationship was no longer significant $\left(R^{2}=0.031, F_{1,6}=0.191, P=0.68\right)$. We recognize the limitation of short-time data series and the influence of outlying points as a bias on small sample sizes. However, the data point is a reflection of increasing reproductive rates and represents all the known breeding females in the study area. In addition, although these density estimates were calculated from known animals and pup counts were made from observation of emergence, a method which may produce unknown bias, these data represent survival of pups, and therefore may at worst have underrepresented reproductive rates.

\section{Coyote Abundance}

Coyote populations, as indexed by aerial hunting efforts, increased in the state of Utah (Fig. $2 ; n=37, r=0.086, P<0.001$ ). Observed increase in the coyote population may be in response to changes in predator management policies with the removal of compound 1080 (sodium fluoroacetate) for predator control. Information on coyote densities on or near DPG was not available, but we assumed that coyote densities at DPG mimicked statewide trends. Both kit fox pre-whelping density $\left(F_{1,6}=86.53, P<0.001\right)$ and kit fox annual density $\left(F_{1,4}=8.03, P=0.047\right)$ were highly correlated with coyote density (Fig. 3).

\section{Small Mammal Abundance}

In the spring of 1999, small mammal abundance was lower in 1 greasewood plot compared to the other $2(H=6.05, P=0.04)$; however, by the following trapping seasons, this population increased. We observed differences among the chenopod habitats where 1 plot's population declined in fall 1999 and did not increase by fall $2000(H=6.30, P=0.04$; spring 2000: $H=7.11, P=0.02$; summer 2000: $H=6.3, P=0.04)$. The population on 1 stable dune plot also decreased dramatically. Only 1 species, mountain cottontail (Sylvilagus nuttalli), was captured in the stable dune plots in spring $2000(H=7.98, P=0.001)$, and again, this population did not increase by late summer 2000 (Fig. 4).

We found that small mammal abundance differed among habitat, season, and year $\left(F_{23,48}=2.73, P=0.002\right)$, with year $(P=$ $0.005)$ and habitat $(P=0.001)$ contributing significantly to the model. Abundance of small mammals in the shrubsteppe habitat was greater $(P \leq 0.05)$ than in all other habitats. In 

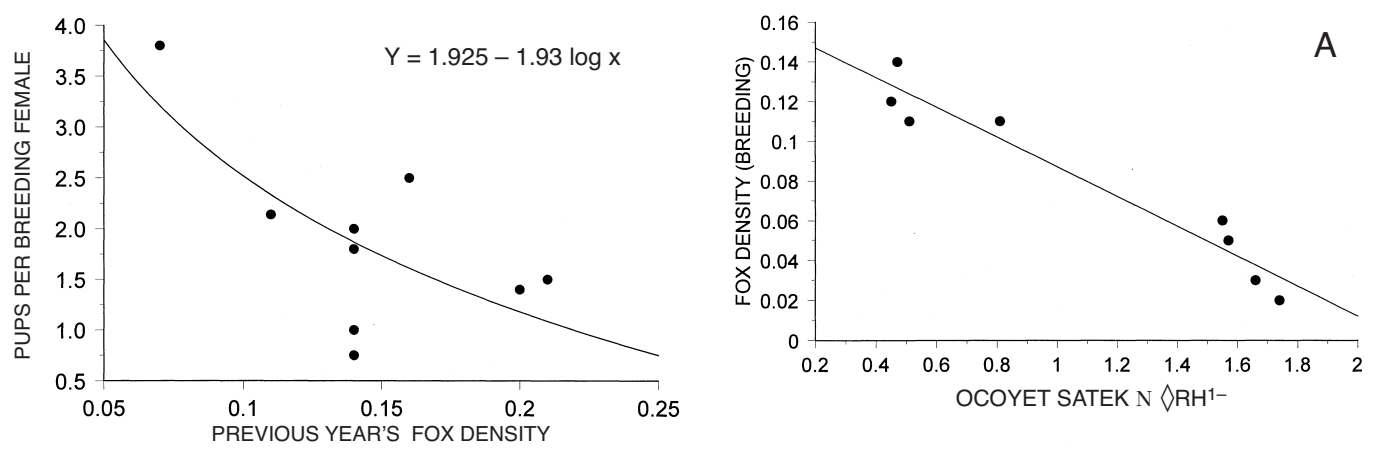

Fig. 1. Relationship between reproductive rate (pups per breeding female) of current year and annual fox density from previous year, U.S. Army Dugway Proving Ground, Utah.

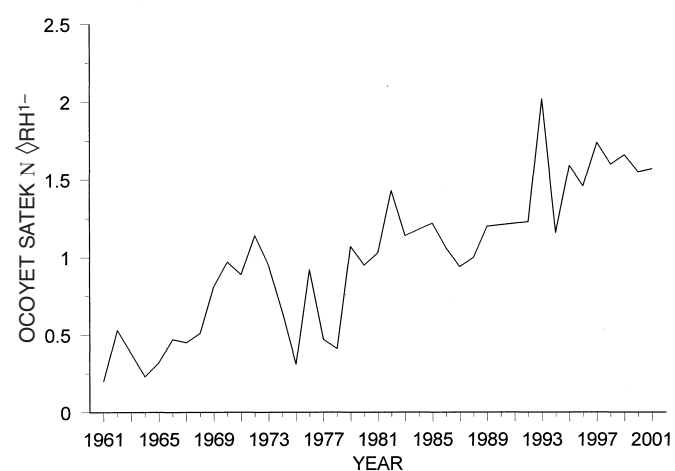

Fig. 2. Coyotes taken per hour of aerial hunting from 1961 through 2001 in Utah. Data from USDA APHIS Wildlife Services.

addition, small mammal abundances in the stable dune and greasewood habitats were greater than in grasslands $(P \leq 0.05)$. Species composition among habitats also differed. Species diversity in the stable dunes $\left(H^{\prime}=\right.$ $0.61)$ was greater than in all of the other habitats in spring 1999 (shrubsteppe: $P=0.01$; greasewood: $P=0.003$; grassland: $P=0.04$; and chenopod and pickleweed habitats: $P=$ 0.001). Both the pickleweed and the chenopod habitats in 1999, and the chenopod habitat in 2000 , lacked species diversity (only 1 species was captured). We did not capture any animals in the grasslands in spring 2000. In spring 2000 , both the stable dune and the shrubsteppe habitats had greater species diversity than the greasewood $(P=0.01, P<0.001)$

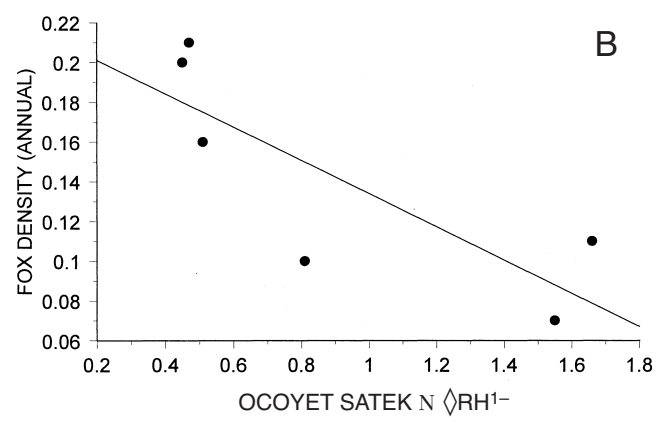

Fig. 3. Relationship between annual numbers of coyotes taken per hour in Utah versus kit fox density during the breeding season (A) and annual kit fox density (individuals $\cdot \mathrm{km}^{-2}$ ) (B), U.S. Army Dugway Proving Ground, Utah.

and pickleweed habitats $(P=0.01, P<0.001)$, respectively.

We found no difference in species diversity in the greasewood plot between historical trapping $\left(H^{\prime}=0.55\right)$ and current trapping periods $\left(H^{\prime}=0.53 ; t=0.14, P>0.5\right)$. There was also no difference between current diversity in the pickleweed plot and historical diversity. We only captured 1 species, deer mouse (Peromyscus maniculatus), in the pickleweed habitat, whereas Vest (1962) also captured white-tailed antelope squirrels (Ammospermophilus leucurus) there. A difference in species diversity was observed in the stable dune plots $\left(1956 / 1957: H^{\prime}=0.71 ; 1999 / 2000\right.$ : $\left.H^{\prime}=0.53 ; t=3.83, P<0.001\right)$ and the shrubsteppe habitats (1956/1957: $H^{\prime}=0.62 ; 1999 /$ 2000: $\left.H^{\prime}=0.47 ; t=2.11, P=0.04\right)$. Vest (1962) captured 9 different species in the stable dunes, and we only captured 5 . In the shrubsteppe/ mixed-brush habitat, Vest (1962) captured 10 species and we captured 4. A sharp decrease in small mammal abundance was observed in 1996 and 1997 (AGEISS 1998); however, the populations appeared to increase slightly in 


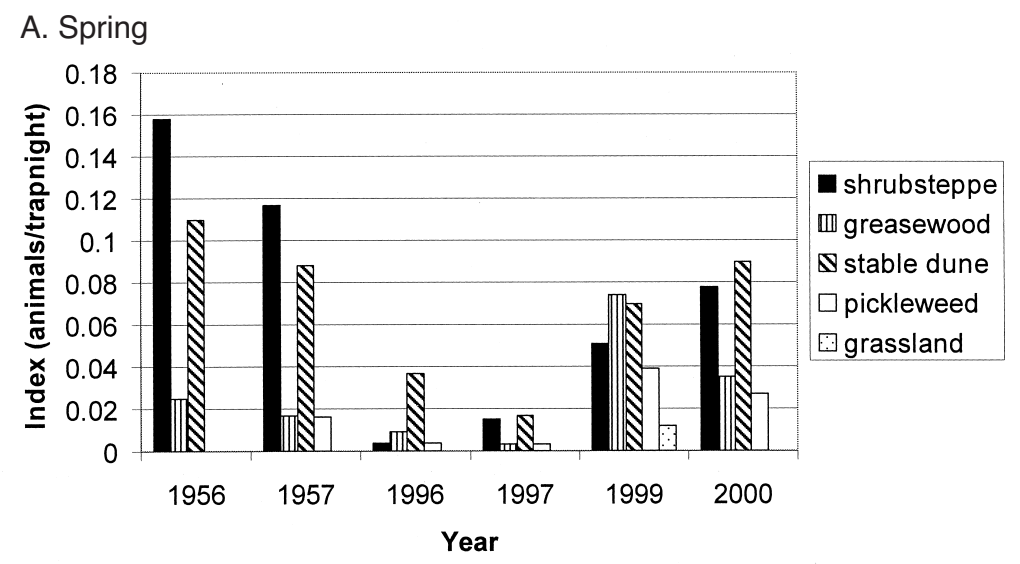

\section{B. Summer}

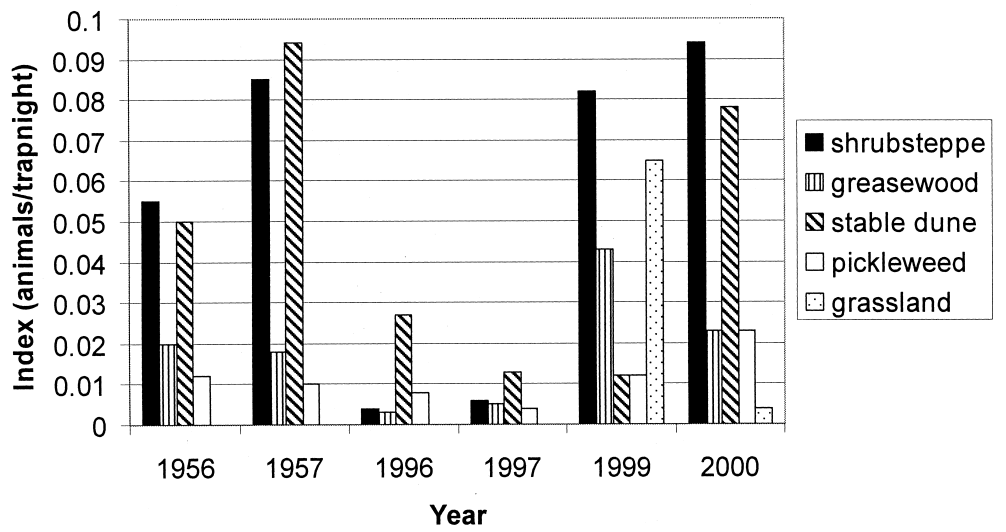

Fig. 4. Index of small mammal abundance in 4 habitats during spring (A) and summer (B), U.S. Army Dugway Proving Ground, Utah.

1999 as a result of generalist species like the deer mouse. Small mammal indices in both spring $\left(r=0.36, F_{1,8}=1.2, P=0.31\right)$ and summer $\left(r=0.26, F_{1,8}=0.63, P=0.45\right)$ were not correlated with precipitation from the current year.

\section{Leporid Abundance}

Leporid abundance along the 6 transects appeared to vary between pre- and postreproductive seasons $\left(F_{11,18}=2.18, P=0.068\right)$. In addition, leporid abundance varied among years $\left(F_{7,10}=5.01, P=0.01\right)$. Total May leporid abundance was $0.45 \pm 0.18\left(s_{\bar{x}}\right)$ leporids · $\mathrm{km}^{-1}$ in 1999 , and $0.17 \pm 0.04$ leporids $\cdot \mathrm{km}^{-1}$ in 2000. An increase in leporid abundance was observed in $2001\left(0.92 \pm 0.28\right.$ leporids $\left.\cdot \mathrm{km}^{-1}\right)$ from 1999 abundance. Although leporid abundance in August was greater than the abundance observed in May, numbers were still not near the historical values (Fig. 5). Historical leporid abundance ranged from a low in 1985 of 0.17 leporids $\cdot \mathrm{km}^{-1}$ to a high in 1971 of 4.96 leporids $\cdot \mathrm{km}^{-1}$ in August and appeared to fluctuate on a 10-year cycle (Fig. 5). The highest number of leporids we recorded during the August surveys was 1.03 leporids · $\mathrm{km}^{-1}$ in 2000 , which should have represented the next peak in leporid density. We realize the limitation of comparing night and day surveys; however, the data still showed the dramatic decline in leporid densities by 2000 even when we used a more reliable technique like spotlight surveys. Although 2000 showed an upward trend in the leporid cycle, this peak was 2 times lower than previous cyclic highs (Fig. 5). Had we conducted these surveys in the daytime, our results would have been even lower. 


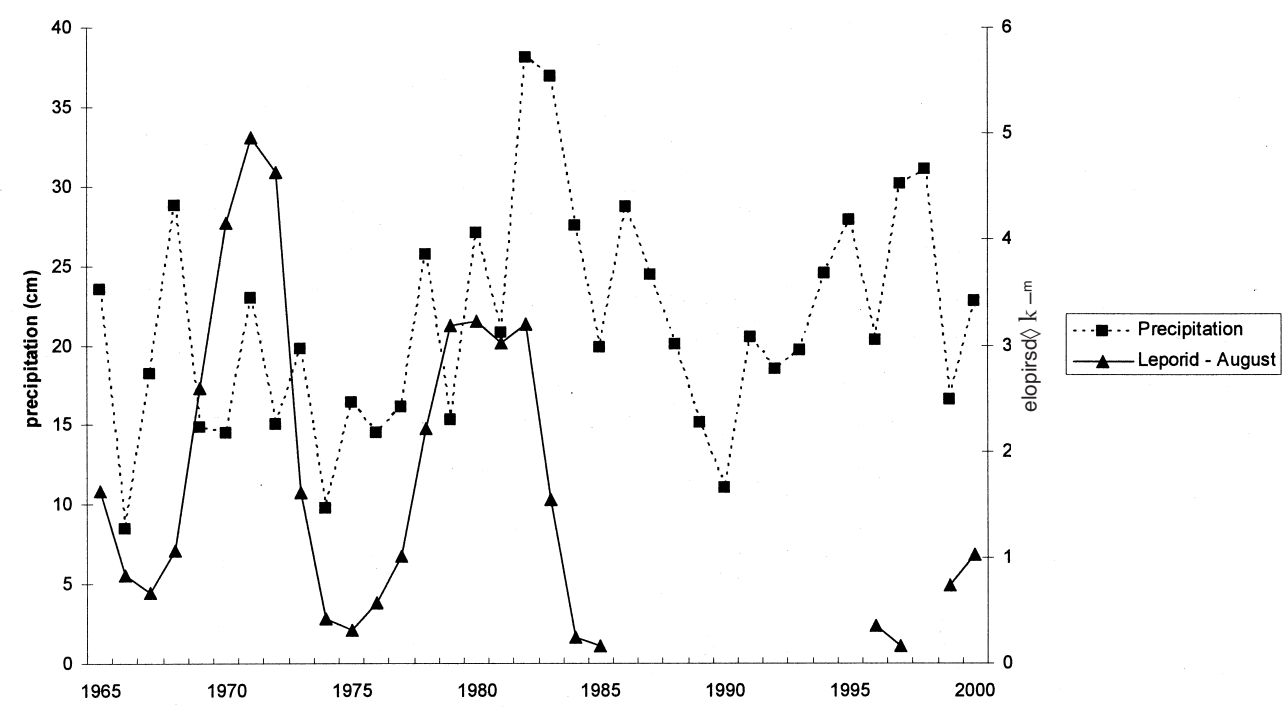

Fig. 5. Index of leporid abundance during August 1965-1985 and 1996-2000, U.S. Army Dugway Proving Ground, Utah.

To compare data collected during previous years (1966-1968, 1996-1997), we used August surveys to calculate leporid abundance along 2 common transects. Leporid abundance ranged from 0.7 to 1.1 leporids $\cdot \mathrm{km}^{-1}$ from 1966 to 1968 (Eberhardt and VanVoris 1986). Abundance decreased to $0.39 \pm 0.04$ and 0.15 leporids $\cdot \mathrm{km}^{-1}$ in 1996 and 1997 , respectively (TRIES 1997). Leporids appeared to increase in 1999 and 2000 in this area, where abundance averaged 1.0 leporids $\cdot \mathrm{km}^{-1}$ and 1.24 leporids $\cdot \mathrm{km}^{-1}$, respectively.

When we examined the influence of rainfall on leporid abundance, we found no correlation between leporid abundance (1966-1968, 1996-1997, and 1999-2001) and precipitation for the same year $\left(r=0.061, F_{1.23}=0.085, P\right.$ $=0.77)$, the previous year $\left(r=0.114, F_{1,23}=\right.$ $0.305, P=0.59)$, or the previous 2 years $(r=$ $\left.0.275, F_{1,23}=1.88, P=0.18\right)$.

\section{Predator-Prey Relationships}

Changes in prey abundance may induce changes in predator demographics. We found that current leporid abundance was not correlated with kit fox reproduction $(r=0.158$, $\left.F_{1,9}=0.227, P=0.65\right)$ or current kit fox prewhelping density $\left(r=0.382, F_{1,7}=1.20, P=\right.$ 0.31 ); nor were there lag effects of the previous year's leporid abundance on fox reproduction $(P=0.487)$ or density $(P=0.122)$. However, annual fox densities and a 1-year lag in leporid densities were slightly correlated $(r=$ $\left.0.82, F_{1,6}=4.92, P=0.07\right)$. No correlation was observed between the current year's spring small mammal densities and reproductive rates $(P=0.32)$ or annual fox densities $(P=0.51)$. Pre-whelping fox densities were slightly correlated with the spring small mammal indices $(P=0.1)$ and the spring mammal indices from the previous year $(P=0.08)$.

\section{Discussion}

Changes to the landscape of DPG, especially the invasion of cheatgrass and the addition of artificial water sources, have changed the available kit fox habitat and prey species and have increased the abundance of coyotes, the kit fox's major competitor and potential predator. Habitat conversion from native Great Basin shrub communities to an annual grassland monoculture is probably the most important factor that currently limits kit fox density on DPG. Unlike in the 1950s when kit foxes were distributed in the lowland greasewood habitats, kit foxes that are presently on DPG mainly inhabit the grasslands and shrubsteppe of the highland areas and the less suitable chenopod and pickleweed habitats of the lowlands (Arjo et al. 2003, Kozlowski 2005). Egoscue surveyed this highland area during both his study periods, but never documented 
the presence of kit fox (Egoscue personal communication). Warrick and Cipher (1998) reported that a negative association between kit fox captures and development was due to a change in habitat or a direct loss of habitat. Juvenile foxes disperse great distances, do not establish territories on DPG, and have low survivorship, all of which suggest that there is limited available habitat or other limiting resources.

Anthropogenic factors, high adaptability, and a flexible social system have allowed coyotes to exploit habitats that they did not previously occupy. The introduction of surface water sources on DPG in the 1970s likely contributed to the increase in coyote numbers, which in turn affected kit fox den selection (Arjo et al. 2003) and spatial distribution. Kit foxes are able to live independently of free water sources, whereas in the absence of available water, coyotes need to consume 3.5 times the number of prey items that kit foxes do to meet energetic requirements (Golightly and Ohmart 1984). Prior to about the 1970s, yearround water sources consisted of approximately 9 natural springs to support wildlife. The addition of anthropogenic sources from 3 sewage ponds, housing irrigation, and more recently, wildlife catchment ponds has supplemented annual availability of water for wildlife. Coyotes are supported by the manmade water sources, as evidenced by the radiation of all radio-collared coyote core areas from permanent water sources such as the sewage ponds (AGEISS 2001). The red fox population increase observed from recent sightings may also be due to the addition of manmade water sources. Red foxes may provide an additive negative effect on kit fox densities because of the potential higher dietary overlap (White et al. 1994, Walls and White 1995).

Most studies of kit fox-prey relationships focus on 1 prey type: leporids. White and Garroted (1997) found a positive correlation between kit fox density and leporid density using data from several studies. Leporids are part of the kit fox prey base on DPG (Kozlowski 2005), but leporids do not appear to be as important as they were historically, when they comprised $>90 \%$ of the diet of kit foxes (Egoscue 1962, 1975). Egoscue (1975) determined kit fox diet based on prey remains at dens, which may bias the results towards larger prey items; therefore, a direct compari- son between historical and current food resources is not reasonable. Dramatic changes in jackrabbit abundance on DPG, as well as throughout the Great Basin Desert, from a high of 4.96 leporids $\cdot \mathrm{km}^{-1}$ in 1971 to a low of 0.16 leporids $\cdot \mathrm{km}^{-1}$ in 1997 , may have contributed to this change in kit fox diet. Although precipitation has been documented to affect kit fox populations indirectly through changes in prey numbers (Cipher and Scrivener 1992, White and Walls 1993, White et al. 1996, White and Garroted 1997), we did not find a correlation in DPG between precipitation and leporid densities. Precipitation during the study was comparable to other dramatic increases in precipitation which correlated to peaks in leporid abundance the following year, yet leporid numbers from 1999-2000 were significantly depressed.

Food habits, determined from scats collected from both kit foxes and coyotes, indicate that nocturnal rodents and kangaroo rats, with the addition of insects such as Mormon crickets (Anabrus spp.) in the summer, make up a large percentage of the kit fox prey base (Kozlowski 2005). Kit foxes on DPG appear to have switched prey in the last 30 years, probably due to the decline in jackrabbit populations, increased competition with coyotes, and changes in habitat use. Increasing coyote numbers, especially centered in the greasewood habitat, where jackrabbit densities are the greatest, may be limiting availability of this prey item to kit foxes. Although coyotes also rely on rodents and kangaroo rats, rabbits are an important 3rd component of their diet (Kozlowski 2005). We found an increase in small mammal abundance during 1999-2000, up from 1997 and 1998; however, abundance was still lower and species diversity was still reduced in several of the habitats compared to abundance in the 1950s. Overall small mammal abundance remained relatively stable due to the increase in numbers of habitat generalists like deer mice. Limited availability of small mammals in exotic grasslands has most likely had a profound effect on kit foxes inhabiting these areas. With the majority of known kit fox dens contained within the grassland habitat (Arjo et al. 2003), kit foxes may be forced to forage farther from denning sites and to maintain numerous den sites in order to hunt in more profitable habitats (e.g., stable dunes). 
A 1-year or even 2-year lag in numerical response by kit foxes to an increase in precipitation, and hence small mammals, has been documented (White et al. 1996, Cipher et al. 2000, Dennis and Often 2000). This lag in response may be due to a numerical lag in response to prey abundance and the monestrous cycle of the kit fox (Dennis and Often 2000). We did not find a correlation with either current small mammal and leporid numbers or numbers due to the lag response produced by precipitation changes. Kit fox reproductive rates, especially in 2001 , were similar to reproductive rates observed in the 1950s and 1960s, even though leporid densities in May 2001 were lower than in previous years. Some correlation between fox densities and jackrabbit abundance from the previous year was observed, as well as a correlation between pre-whelping fox densities and spring small mammals. Several canid species, like coyotes, are able to increase reproductive effort to compensate for low densities (Ballard et al. 1987, Knowlton and Gese 1995, Windberg 1995). Kit fox reproductive rates on DPG appear to be density dependent, though kit fox densities have decreased from historical levels. Lower numbers may be due to the reduction in available prey items (e.g., leporids or kangaroo rats) and an increase in pressure from competing predators. Not only is kit fox density dependent upon reproductive rates, but also survivorship and recruitment. Adult survivorship in our study was similar to values reported elsewhere (Standley et al. 1992, Walls and White 1995, Spiegel and Disney 1996, Cipher et al. 2000). Although reproductive rates were favorable in the last couple of years, juvenile recruitment into the DPG population seems to be a more limiting factor.

Competition between sympatric canids is well documented (Berg and Chesness 1978, White et al. 1994, Peterson 1995, Arjo and Pletscher 1999). However, some studies suggest that removing coyotes does not affect kit fox abundance unless removals are substantial and sustained (Cipher and Scrivener 1992, White and Garroted 1997). Coyotes were rare during the 1950s and 1960s (Shippee and Jollie 1953, Egoscue personal communication); however, numbers have substantially increased in the last 40 years. Predator-caused mortality was the main source of kit fox mortality in sev- eral studies (Standley et al. 1992, Walls and White 1995, Spiegel and Disney 1996, Cipher et al. 2000). We did not find road mortality to be significant compared to predator mortality, unlike findings from the 1950s (Egoscue 1975). Though coyotes contributed significantly to kit fox mortality, we do not believe that coyotecaused mortality is a proximate cause of decreasing kit fox density. However, competition by coyotes may potentially limit available habitat (Kozlowski 2005). Coexistence between coyotes and kit or swift foxes (V. velox) can be facilitated through partitioning of resources (e.g., prey or habitat) and year-round use of dens (White et al. 1995, Warrick and Cipher 1998, Kitchen et al. 1999); however, the relationship is dependent upon coyote density (Warrick and Cipher 1998). The impact of coyote mortalities on a fox population may be greater during periods of low prey availability and an already-depressed fox population (Walls and White 1995, Kitchen et al. 1999). Red foxes often spatially segregate their home ranges from competing coyotes, even in areas where habitat is generally preferred (Voigt and Earle 1983, Major and Sherburne 1987, Harrison et al. 1989). In areas where both red fox and gray fox (Urocyon cinereoargenteus) co-occur with coyotes, high dietary overlap can cause a decrease in the red fox population, but habitat segregation allows for coexistence with the gray fox (Cipher 1993). Survival for the kit fox population on DPG is dependent on better recruitment and retention of juveniles in the area. This, in turn, is dependent on maintaining a healthy prey population. Ultimately, the conservation of Great Basin habitats and the elimination or substantial reduction of exotic grassland invasions will allow a recovery of the small mammal and leporid community.

Management actions that mitigate and reverse the trend toward exotic grasslands include aggressive fighting of wildfires, limiting off-road maneuvering, replanting native or fire resistant vegetation, removing man-made water sources, and possibly conducting live-fire artillery training in the cooler and more humid spring, fall, and winter months. Although potential competition from coyotes may still exist without a substantial and sustained reduction in density of the larger carnivore, the reestablishment of native habitat and small mammal assemblages may mitigate competition for space and food. 


\section{ACKNOWLEDGMENTS}

We dedicate this paper in memory of $\mathrm{H}$. Egoscue, who passed away shortly after completion of the study. He was instrumental in establishing the foundations of kit fox biology. We appreciated the opportunity of working with H. Egoscue and his willingness to share his unpublished kit fox data. We also thank S. Bates, J. Martin, and S. Plunkett of the Directorate of Environmental Programs at Dugway Proving Ground, Utah, for their logistical and financial support, and M. Bodenchuk of Wildlife Services for providing the coyote data. The field efforts of L. Blake, M. Criffield, E. Groth, T. Kozlowski, B. Louie, S. Lupis, D. Meier, D. Mummert, M. Panasci, and C. Winchester were greatly appreciated. Additional support was provided by USDA APHIS WS National Wildlife Research Center, Logan Field Station. This research was conducted while the senior author was an employee of AGEISS Environmental, Inc. Capture and handling protocols were approved by Institutional Animal Care and Use Committees at the National Wildlife Research Center and Utah State University. Comments from P.J. White and anonymous reviewers were appreciated.

\section{Literature Cited}

AGEISS. 1997. Small mammal survey of historic Woodbury plots. U.S. Army Dugway Proving Ground, Dugway, UT.

1998. 1998 small mammal survey of historic Woodbury plots. U.S. Army Dugway Proving Ground, Dugway, UT.

.2001. Final report for the carnivore ecology study at Dugway Proving Ground. U.S. Army Dugway Proving Ground, Dugway, UT.

ARJo, W.M., T.J. BennetT, AND A.J. Kozlowski. 2003. Characteristics of current and historical kit fox (Vulpes macrotis) dens in the Great Basin desert. Canadian Journal of Zoology 81:96-102.

ARJo, W.M., AND D.H. Pletscher. 1999. Behavioral responses of coyotes to wolf recolonization in northwestern Montana. Canadian Journal of Zoology 77: 1919-1927.

Ballard, W.B., J.S. Whitman, and C.L. Gardner. 1987. Ecology of an exploited wolf population in southcentral Alaska. Wildlife Monographs 98:1-54.

Berg, W.E., And R.A. Chesness. 1978. Ecology of coyotes in northern Minnesota. Pages 229-247 in M Bekoff, editor, Coyotes: biology, behavior, and management. Academic Press, New York.

Carpenter, L.M., AND W.M. ARJo. 1999. Exotic annuals and changes in small mammal communities. Journal of the Colorado-Wyoming Academy of Science 31(1):6.

CiphER, B.L. 1993. Food item use by three sympatric canids in southern Illinois. Transactions of the Illinois State Academy of Science 86:139-144.
Cipher, B.L., And J.H. Scrivener. 1992. Coyote control to protect endangered San Joaquin kit foxes at the Naval Petroleum Reserves, California. Pages 42-47 in J.E. Borrecco and R.E. Marsh, editors. Proceedings of the 15th Vertebrate Pest Conference. University of California, Davis.

Cipher, B.L., AND K.A. SPEnCER. 1998. Competitive interactions between coyotes and San Joaquin kit foxes. Journal of Mammalogy 79:204-214.

Cipher, B.L., G.D. Warkick, M.R.M. Often, T.P. O’FarRELL, W.H. Berry, C.E. Harris, T.T. Kato, et al. 2000. Population dynamics of San Joaquin kit foxes at the Naval Petroleum Reserves in California. Wildlife Monographs 145:1-43.

Dennis, B., AND M.R.M. Often. 2000. Joint effects of density dependence and rainfall on abundance of San Joaquin kit fox. Journal of Wildlife Management 64:388-400.

E \& E Research Grour. 1967. A study of the ecology and epizoology of the native fauna of the Great Salt Lake Desert, 1966. Annual summary review to Dugway Proving Ground. Salt Lake City, Utah.

1968. A study of the ecology and epizoology of the native fauna of the Great Salt Lake Desert, 1967. Annual summary review to Dugway Proving Ground. Salt Lake City, Utah.

.1969. A study of the ecology and epizoology of the native fauna of the Great Salt Lake Desert, 1968. Annual summary review to Dugway Proving Ground. Salt Lake City, Utah.

1970. A study of the ecology and epizoology of the native fauna of the Great Salt Lake Desert, 1969. Annual summary review to Dugway Proving Ground. Salt Lake City, Utah.

Eberhardt, L.E., AND P. Van Voris. 1986. Historical wildlife dynamics on Dugway Proving Ground: population and disease trends in jack rabbits over two decades. Prepared for the U.S. Army Test and Evaluation Command. Contract No. DE-AC06-76RLO1830.

Egoscue, H.J. 1956. Preliminary studies of the kit fox in Utah. Journal of Mammalogy 37:351-357.

. 1962. Ecology and life history of the kit fox in Tooele County, Utah. Ecology 43:481-497.

. 1975. Population dynamics of the kit fox in western Utah. Bulletin (Southern California Academy of Sciences) 74:122-127.

Emrick, V., AND A. Hill. 1998. Classification of the Great Basin plant communities occurring on Dugway Proving Ground, Utah. U.S. Army Corp of Engineers Research Laboratories.

Fuller, T.K., AND P.R. SAvored. 2001. Carnivore demography and the consequences of changes to prey availability. Pages 163-178 in J.L. Gittleman, S.M. Funk, D. MacDonald, and R.K.Wayne, editors, Carnivore conservation. Cambridge University Press.

Gese, E.M., O.J. Rongstad, and W.R. Mytton. 1988. Relationships between coyote group size and diet in southeastern Colorado. Journal of Wildlife Management 52:647-653.

Golightly, R.T., Jr., and R.D. Ohmart. 1984. Water economy of two desert canids: coyote and kit fox. Journal of Mammalogy 65:51-58.

Harrison, D.J., J.A. Bissonette, and J.A. Sherburne. 1989. Spatial relationships between coyotes and red foxes in eastern Maine. Journal of Wildlife Management 53:181-185. 
HeIsey, D.M., AND T.K. Fuller. 1985. Evaluation of survival and cause-specific mortality rates using radio telemetry data. Journal of Wildlife Management 49: 668-674.

Kitchen, A.M., E.M. Gese, and E.R. Schauster. 1999. Resource partitioning between coyotes and swift foxes: space, time, and diets. Canadian Journal of Zoology 77:1645-1656.

Knowlton, F.F., AND E.M. Gese. 1995. Coyote population processes revisited. Pages 1-6 in C. Richardson, T. Blankenship, K. Canon, and S. Henke, editors, Proceedings on coyotes in the Southwest: a compendium of our knowledge. Texas Parks and Wildlife Department, San Angelo.

KozLowsKi, A.J. 2005. An examination of the asymmetrical interactions of sympatric kit foxes and coyotes in Utah's West Desert. Master's thesis, Utah State University, Logan.

Major, J.T., AND J.A. Sherburne. 1987. Interspecific relationships of coyotes, bobcats, and red foxes in western Maine. Journal of Wildlife Management 51:606616.

O’Neal, G.T., J.T. Flinders, and W.P. Clary. 1987. Behavioral ecology of the Nevada kit fox (Vulpes macrotis nevadensis) on a managed desert rangeland. Pages 443-481 in H.H. Genoways, editor, Current mammalogy. Plenum Press, New York.

Peterson, R.O. 1995. Wolves as interspecific competitors in canid ecology. Pages 315-323 in L.N. Carbyn, S.H. Fritts, and D.R. Seip, editors, Ecology and conservation of wolves in a changing world. Canadian Circumpolar Institute, Edmonton, Alberta, Canada.

Pierce, B.M., V.C. Bleich, and R.T. Bowyer. 2000. Social organization of mountain lions: Does a land-tenure system regulate population size? Ecology 81:15331543.

Pooele, K.G., L.A. Wakelyn, and P.N. Nicklen. 1996. Habitat selection by lynx in the Northwest Territories. Canadian Journal of Zoology 74:845-850.

Schauster, E.R., E.M. Gese, And A.M. Kitchen. 2002. An evaluation of survey methods for monitoring swift fox abundance. Wildlife Society Bulletin 30:464-477.

ShippeE, E.A., AND W.P. JolliE. 1953. Report of predator control operations. Ecology of the Great Salt Lake Desert, semi-annual report. University of Utah, Salt Lake City.

Spiegel, L.K., AND M. Disney. 1996. Mortality sources and survival rates of San Joaquin kit fox in oil-developed and undeveloped lands of southwestern Kern County, California. Pages 71-92 in L.K. Spiegel, editor, Studies of the San Joaquin kit fox in undeveloped and oil-developed areas. California Energy Commission, Sacramento.

Standley, W.G., W.H. Berry, T.P. O'Farkell, and T.T. KaTO. 1992. Mortality of San Joaquin kit fox at Camp Roberts Army National Guard training site, Cali- fornia. U.S. Department of Energy Topical Report No. EGG 10627-2157.

[TRIES] Texas Research Institute for EnvironmenTAL STUDIES. 1997. Canid community ecology and response to Army National Guard training at U.S. Army Dugway Proving Ground, Dugway, Utah. Report to the Directorate of Environmental Programs, Dugway Proving Ground, Dugway, UT.

VEST, D.E. 1962. The plant communities and associated fauna of Dugway Valley in western Utah. Doctoral dissertation, University of Utah, Salt Lake City.

VoigT, D.R., AND B.D. EARLE. 1983. Avoidance of coyotes by red fox families. Journal of Wildlife Management 47:852-857.

WaLls, K., AND P.J. White. 1995. Predation on San Joaquin kit foxes by larger canids. Journal of Mammalogy 76:723-729.

Warrick, G.D., AND B.L. CipHER. 1998. Factors affecting the spatial distribution of San Joaquin kit foxes. Journal of Wildlife Management 62:707-717.

White, G.C., AND R.A. GaRRoted. 1990. Analysis of radiotracking data. Academic Press, Inc., New York.

White, P.J., AND R.A. Garroted. 1997. Factors regulating kit fox populations. Canadian Journal of Zoology 75:1982-1988.

1999. Population dynamics of kit foxes. Canadian Journal of Zoology 77:486-493.

White, P.J., C.A. Vanderbilt White, and K. Walls. 1996. Functional and numerical responses of kit foxes to a short-term decline in mammalian prey. Journal of Mammalogy 77:370-376.

White, P.J., and K. Walls. 1993. Reproduction and spacing patterns of kit foxes relative to changing prey availability. Journal of Wildlife Management 57:861867.

White, P.J., K. Walls, and R.A. Garroted. 1994. Coyote-kit fox interaction as revealed by telemetry. Canadian Journal of Zoology 72:1831-1836.

White, P.J., K. Walls, and C.A. Vanderbilt White. 1995. Overlap in habitat and food use between coyotes and San Joaquin kit foxes. Southwestern Naturalist 40:342-349.

WindBerg, L.A. 1995. Demography of a high-density coyote population. Canadian Journal of Zoology 74: 942-954.

ZAR, J.H. 1996. Biostatistical analysis. Prentice Hall, Inc., Upper Saddle River, NJ.

Zoellick, B.W., and N.S. Smith. 1992. Size and spatial organization of home ranges of kit foxes in Arizona. Journal of Mammalogy 73:83-88.

Zoellick, B.W., N.S. Smith, and R.S. Henry. 1989. Habitat use and movements of desert kit foxes in western Arizona. Journal of Wildlife Management 53:955-961.

Received 25 April 2006 Accepted 22 November 2006 